\title{
Genetic Hybridization of the leu-ilv Region in Bacilli
}

\author{
By G. D. BISWAS* AND A. W. RAVIN \\ Department of Biology, University of Chicago, Chicago, Illinois 60637, U.S.A.
}

(Received 23 June 1975; revised 23 September 1975)

\begin{abstract}
SUMMARY
Two auxotrophic strains of Bacillus subtilis 168 served as recipients for DNA extracted from various wild-type strains of $B$. subtilis and wild-type species of the genus Bacillus. Depending upon the DNA source, heterologous transformations of the linked try-his-tyr loci were either as efficient as those observed with donor DNA obtained from the wild-type B. subtilis I 68 strain or were undetectable. The order and relative distances of the three gene loci were the same for all active DNA preparations. Similar results were obtained in heterologous transformations of the linked leu-ilv loci, except that DNA preparations from the Bacillus globigii and $B$. subtilis var. niger species exhibited a reduced but detectable frequency of transformation. With the latter preparations a marked polarity of integration favouring the $l e u^{+}$gene was observed, an effect not seen with homologous DNA. Six independent hybrid lines were obtained from transformation of $B$. subtilis $l e u^{-} i l v^{-}$with DNA from $B$. subtilis var. niger leu $i l v^{+}$. DNA extracted from these lines fell into two classes on the basis of activity in transforming the parental recipient strain: (i) indistinguishable from homologous DNA, and (ii) intermediate between homologous DNA and DNA from the original donor strain. With either class, polarity of integration was no longer observed in the leu-ilv region. The intermediate type of hybrid demonstrates that at least some of the inefficiency of heterospecific transformation must be due to heterology in nucleotide sequence between the different species at the leu-ilv loci.
\end{abstract}

\section{INTRODUCTION}

The inefficiency of transformation by heterospecific DNA could, in principle, be due to any one of a number of conditions, including restriction of host-modified bases and heterology between the base sequences of donor and recipient genomes. That a substantial part of the inefficiency is, in fact, due to the latter is indicated by the production, in heterospecific transformation, of genetically hybrid DNA (donor sequences heritably linked to recipient sequences) that is intermediate in its transforming properties between the DNAs of the original donor and recipient (Biswas \& Ravin, 1971; Wilson \& Young, 1972; Ravin \& Chakrabarti, 1975).

In a study of Bacillus globigii and two different strains of B. subtilis, Chilton \& McCarthy (I969) found that, while heterospecific transformation could not be detected at most genetic loci, transformation did occur, albeit with reduced efficiency, at two well-separated regions of the genome, str and leu-ilv. These findings were taken to mean that, in the evolution of Bacillus strains, sequence differentiation occurred at a slower rate in the str and leu-ilv loci than in the remainder of the genome. We have been able to extend these findings in an

* Present address: Departments of Bacteriology and Medicine, The School of Medicine, University of North Carolina, Chapel Hill, North Carolina, U.S.A. 
examination of additional strains. Moreover, we have produced genetically intermediate hybrids in the leu-ilv region, demonstrating that base sequence changes in this region are correlated with the formation of species.

\section{METHODS}

Bacterial strains. The recipient strains used in these experiments were SB202B and WB2713. Both are derivatives of Bacillus subtilis I68. Strain SB202B is triply auxotrophic for the linked $\operatorname{trpC2}$, his $\mathrm{Hz}$, tyrAI markers, having been produced by transforming strain $\mathrm{SB} 202$ (aroBz trpC2 hisHz tyrAI; Nester, Schafer \& Lederberg, 1963) with DNA from the prototrophic strain 746 and selecting for aro $^{+}$. Strain WB27I3 carries the linked leu-8 and $i l v A I$ markers (Chilton \& McCarthy, 1969). The homologous strain used as prototrophic donor in all experiments was 746 , a streptomycin-resistant descendant of the 168 strain (Chilton \& McCarthy, 1969). Strains SB202, WB2713 and 746 were obtained from Dr Mary-Dell Chilton. The heterologous strains used as donors are listed in Table I. All with an ATCC number were obtained from the American Type Culture Collection. Bacillus natto strain B275d was a gift of the Merck, Sharp and Dohme Co. The w23 strain of B. subtilis originated with Dr $\mathrm{N}$. Sueoka and was supplied by Dr Chilton. Bacillus amyloliquefaciens strain N was furnished by Dr L. L. Campbell, and B. stearothermophilus by Dr N. Welker.

Preparation of transforming DNA. DNA was prepared by the method of Saito \& Miura (1963). The concentration was determined by the method of Hotchkiss (1957).

Preparation of competent cells and transformation procedure. Competent recipients were obtained by a modification of the method of Bott \& Wilson (1967, 1968). Batches were either used when prepared or stored by freezing at $-70{ }^{\circ} \mathrm{C}$ in the presence of $15 \%(\mathrm{w} / \mathrm{v})$ glycerine before use. The medium in which the cells became competent was Spizizen's (1958) minimal medium, to which was added $50 \mu \mathrm{g}$ each of tryptophan, histidine, and tyrosine $/ \mathrm{ml}$ for strain SB202, or $16 \mu \mathrm{g}$ each of leucine, isoleucine, and valine $/ \mathrm{ml}$ for strain WB2713. To transform competent recipients, I part of the appropriate DNA solution was added to 9 parts of culture in a test tube or small flask. This was placed in a reciprocal-shaking water bath (New Brunswick model R76) at $37^{\circ} \mathrm{C}$ and shaken at speed setting 7 . The final concentration of DNA was I $\mu \mathrm{g} / \mathrm{ml}$ unless otherwise indicated. After $30 \mathrm{~min}$ the reaction with DNA was stopped by the addition of $\mathrm{Mg}^{2+}$-activated pancreatic DNAase I (final concn $0.1 \mathrm{mg} / \mathrm{ml}$ ). The culture was shaken at $37^{\circ} \mathrm{C}$ for an additional $10 \mathrm{~min}$, centrifuged in the cold (o to $4{ }^{\circ} \mathrm{C}$ ), the supernatant discarded and the pellet washed once and then resuspended in Spizizen's medium lacking glucose and amino acids. Dilutions of the suspension were plated on minimal agar with the appropriate amino acid supplement(s) at the concentrations indicated above. Plates were incubated at $37^{\circ} \mathrm{C}$ and colonies counted after $40 \mathrm{~h}$ to determine the number of transformants in the culture, which had contained a total of about $2 \times 1 \mathrm{C}^{8}$ cells $/ \mathrm{ml}$. Since competence varied as much as sevenfold in different preparations of recipient cultures (Tables I and 2), a single preparation was always used for comparing DNA activities.

Measurement of linkage. Over 100 transformant colonies that had been selected for a single marker were picked by means of a sterile needle or toothpick and transferred to sectors of non-selective agar medium. After suitable incubation, the latter plates were replicated with sterile velvet on to solid media differing in number and kinds of amino acid supplements so as to test for unselected markers. The number of transformants in each recombinant class was calculated in the usual way (Nester et al., I963). Linkage is expressed as the proportion of tested colonies containing an unselected donor marker in the following way: $l e u^{+} i l v^{+} / l e u^{+}$, or $l e u^{+} i l v^{+} / i l v^{+}$. 


\section{RESULTS}

\section{Transformation and linkage in the trp-his-tyr region}

DNA preparations from an homologous source (strain 746) and from the strains of Bacillus listed in Table I (except B. amyloliquefaciens) were tested for their ability to transform B. subtilis SB202B to partial or multiple prototrophy at the linked trp-his-tyr loci. With one exception, DNA from no species other than $B$. subtilis was able to produce transformants at any of these loci. (The one exception, $B$. natto, however, is believed to be a strain of $B$. subtilis; Smith, Gordon \& Clark, 1946.) DNA from some strains classified as B. subtilis (ATCC9799, ATCC82 and ATCC6984) and from a variant of B. subtilis (var. niger, ATCC6455) was also unable to transform strain SB202B for these markers. All the DNA preparations that did transform, did so with efficiencies similar to those observed with homologous (746) DNA. Moreover, those heterologous DNA preparations that did transform manifested similar linkage between the three loci. The linear order trp-his-tyr, with his being closer to tyr than to trp, first demonstrated by Nester et al. (1963), was observed for each of the DNA preparations examined for linkage.

\section{Transformation and linkage in the leu-ilv region}

Transformation in the leu-ilv region provided a somewhat different picture (Table 1). DNA that was effective in transforming the trp-his-tyr region of strain SB202B was also effective in transforming the leu-ilv region of strain wB27r3. With two exceptions, DNA preparations that were ineffective in transforming the trp-his-tyr region were also ineffective in transforming the leu-ilv region. In addition, DNA from a strain of B. amyloliquefaciens was ineffective in transforming the leu-ilv region; it was not tested for transformation of the trp-his-tyr region.

The two DNA preparations that failed to transform the trp-his-tyr region but did transform the leu-ilv region came from B. subtilis var. niger (AтCC6455) and from B. globigii. There were two interesting features of the leu-ilv transformations induced by these DNA preparations: (i) while transformations did occur, they took place with a frequency that was distinctly lower than that observed with an homologous DNA. Moreover, Bacillus globigii DNA was over an order of magnitude less effective than B. subtilis var. niger DNA. (ii) With either DNA, transformation at the ilv locus occurred with a tenfold lower frequency than transformations at the leu locus. In contrast, $l e u^{+}$and $i l v^{+}$transformations occurred with nearly identical frequencies when homologous DNA was used.

\section{Hybrids in the leu-ilv region}

Six independent transformants of $B$. subtilis induced by DNA from $B$. subtilis var. niger were isolated: two were selected as double $l e u^{+} i l v^{+}$transformants, two as single $l e u^{+} i l v^{-}$ transformants, and two as single $l e u^{-} i l v^{+}$transformants. DNA was prepared from each of these strains and tested for activity in transforming the original $l e u^{-} i l v^{-}$recipient (strain WB2713). As controls, homologous DNA (746) and heterologous DNA from the original donor (B. subtilis var. niger) were regularly used. In addition, we tested DNA extracted from a number of transformants produced by homologous DNA (746) in strain WB27I3. The latter are listed in Table 2 as DNA from homospecific transformants (hom. tr.) in contradistinction to DNA from transformants produced in a heterologous cross (hybrids, or Hyb.).

Different preparations from the same source sometimes varied in activity by as much as 
Table $\mathrm{I}$. Interstrain and interspecific transformation of B. subtilis WB27 3

\begin{tabular}{|c|c|c|c|c|c|}
\hline \multicolumn{2}{|l|}{ Donor } & \multirow[b]{2}{*}{ Expt. no.* } & \multicolumn{3}{|c|}{$10^{-5} \times$ No. of transformants $/ \mathrm{ml}$} \\
\hline Species & $\begin{array}{c}\text { Strain } \\
\text { designation }\end{array}$ & & $l e u^{+}$ & $\overbrace{i l v^{+}}$ & $l e u^{+} i l v^{+}$ \\
\hline \multirow[t]{13}{*}{ Bacillus subtilis } & 746 & I & $4 \cdot 2$ & $3 \cdot 5$ & ND \\
\hline & & 2 & $2 \cdot 2$ & 1.9 & 0.93 \\
\hline & & 3 & $1 \cdot 2$ & $1 \cdot 7$ & 0.67 \\
\hline & & 4 & $4 \cdot 2$ & $4 \cdot 2$ & $\mathrm{I} \cdot 5$ \\
\hline & & 5 & $8 \cdot 3$ & $6 \cdot 8$ & ND \\
\hline & ATCCI 5819 & 2 & 0.5 & 0.5 & 0.19 \\
\hline & ATCC 6633 & 2 & $1 \cdot 7$ & $1 \cdot 0$ & 0.46 \\
\hline & ATCC 465 & 2 & $5 \cdot 6$ & $3 \cdot 7$ & $2 \cdot 7$ \\
\hline & ATCC4529 & 2 & $3 \cdot 8$ & $4 \cdot 2$ & $2 \cdot 7$ \\
\hline & ATCC605I-a & 2 & $3 \cdot 2$ & $2 \cdot 7$ & $1 \cdot 3$ \\
\hline & $\operatorname{ATCC} 605 \mathrm{I}-2$ & 2 & $I \cdot 9$ & $\mathbf{I} \cdot 6$ & 0.73 \\
\hline & ATCC 4944 & 2 & 3.9 & $3 \cdot I$ & $I \cdot 9$ \\
\hline & w23 & 3 & 0.73 & 0.44 & $0 \cdot 16$ \\
\hline B. subtilis var. aterrimus & ATCC7060 & 2 & $4 \cdot 3$ & $3 \cdot 8$ & $I \cdot 7$ \\
\hline B. natto & B275d & 2 & $4 \cdot 3$ & $3 \cdot 1$ & $2 \cdot 2$ \\
\hline \multirow[t]{2}{*}{ B. subtilis var. niger } & ATCC6455 & I & 0.085 & 0.0085 & ND \\
\hline & & 4 & 0.070 & 0.0062 & 0.0018 \\
\hline \multirow[t]{2}{*}{ B. globigii } & & I & 0.00 II & 0.0001 & ND \\
\hline & & 5 & 0.0019 & 0.0005 & ND \\
\hline B. amyoliquefaciens & $\mathbf{N}$ & I & $<10^{-7}$ & $<10^{-7}$ & ND \\
\hline \multirow[t]{3}{*}{ B. subtilis } & ATCC9799 & I & $<\mathrm{IO}^{-7}$ & $<\mathrm{IO}^{-7}$ & ND \\
\hline & ATCC 82 & I & $<10^{-7}$ & $<10^{-7}$ & ND \\
\hline & ATCC6984 & 1 & $<10^{-7}$ & $<\mathrm{IO}^{-7}$ & ND \\
\hline \multirow[t]{4}{*}{ B. licheniformis } & ATCCI 4580 & I & $<10^{-7}$ & $<\mathrm{IO}^{-7}$ & ND \\
\hline & ATCC6598 & I & $<10^{-7}$ & $<\mathrm{IO}^{-7}$ & ND \\
\hline & ATCC 9789 & 1 & $<10^{-7}$ & $<10^{-7}$ & ND \\
\hline & ATCC6634 & 1 & $<10^{-7}$ & $<10^{-7}$ & ND \\
\hline B. polymyxa & ATCC 842 & I & $<10^{-7}$ & $<10^{-7}$ & ND \\
\hline B. stearothermophilus & & I & $<\mathrm{IO}^{-7}$ & $<10^{-7}$ & ND \\
\hline No DNA & & $1-5$ & $<10^{-7}$ & $<10^{-7}$ & ND \\
\hline
\end{tabular}

ND, Not done.

* Different batches of competent cells were used in different experiments.

fivefold (expts IV and V, Table 2). Yet the heterologous DNA preparation was always more than an order of magnitude lower in activity than the homologous preparation, regardless of the competence of the recipient cells (expts I, II, III and V, Table 2). DNA from six independent homologous transformants, whether initially selected for $\mathrm{leu}^{+}$or $\mathrm{ilv}^{+}$alone or for both markers, was always within the same range of activity as DNA from the original donor parent (expts I to III, Table 2). While DNA from the hybrids never showed the same low activity that the heterologous DNA manifested, two distinct types of hybrids were observed. One type contained DNA that was not readily distinguishable in activity from that of the homologous donor; this was true of hybrids I $\left(l e u^{+} i l v^{+}\right), 3\left(l e u^{+} i l v^{-}\right)$, and possibly $4\left(l e u^{+} i l v^{-}\right)$. The other type contained DNA that was intermediate in activity between that of the original heterologous donor and that of the homologous donor; this was true of hybrids $2\left(l e u^{+} i l v^{+}\right), 5\left(l e u^{-} i l v^{+}\right)$and $6\left(l e u^{-} i l v^{+}\right)$.

With DNA from either type of hybrid, $l e u^{+}$and $i l v^{+}$transformations were induced equally frequently, despite the fact that $i l v^{+}$was less active in the original heterologous DNA. This 
Table 2. Efficiency of transformation of B. subtilis WB27I 3 and linkage in the leu-ilv region using DNA from homologous, heterologous and hybrid sources

\begin{tabular}{|c|c|c|c|c|c|c|c|}
\hline \multirow{3}{*}{$\begin{array}{l}\text { Expt. } \\
\text { no.* }\end{array}$} & \multirow{2}{*}{\multicolumn{3}{|c|}{ Donor DNA }} & \multirow{2}{*}{\multicolumn{2}{|c|}{$\begin{array}{c}10^{-5} \times \text { No. of } \\
\text { transformants } / \mathrm{ml}\end{array}$}} & \multicolumn{2}{|c|}{ Linkage§ } \\
\hline & & & & & & \multirow{2}{*}{$\frac{l e u^{+} i l v^{+}}{l e u^{+}}$} & \multirow{2}{*}{$\frac{l e u^{+} i l v^{+}}{i l v^{+}}$} \\
\hline & Source $\dagger$ & Designatior & & $\mathrm{leu}^{+}$ & $i l v^{+}$ & & \\
\hline \multirow[t]{6}{*}{ I } & Hom. & 746 & $\left(l e u^{+} i l v^{+}\right)$ & $I \cdot O$ & $\mathrm{I} \cdot 7$ & ND & ND \\
\hline & Hom. tr. & $2713 \times 764$ (No. 1$)$ & $\left(l e u^{+} i l v^{+}\right)$ & $I \cdot 4$ & $1 \cdot 7$ & ND & ND \\
\hline & Hom. tr. & $2713 \times 764$ (No. 2$)$ & $\left(l e u^{+} i l v^{+}\right)$ & 0.4 & 0.7 & ND & ND \\
\hline & Het. & 6455 & $\left(l e u^{+} i v^{+}\right)$ & 0.009 & 0.003 & ND & ND \\
\hline & Hyb. & $2713 \times 6455$ (No. I ) & $\left(l e u^{+} i l v^{+}\right)$ & 0.4 & 0.3 & ND & ND \\
\hline & Hyb. & $2713 \times 6455$ (No. 2$)$ & $\left(l e u^{+} i l v^{+}\right)$ & 0.05 & 0.04 & ND & ND \\
\hline \multirow[t]{8}{*}{ II } & Hom. & 746 & $\left(l e u^{+} i l v^{+}\right)$ & $I \cdot 2$ & $I \cdot 3$ & 0.35 & 0.51 \\
\hline & Hom. tr. & $2713 \times 764$ (No. 2$)$ & $\left(l e u^{+} i v^{+}\right)$ & 0.7 & $0 \cdot 7$ & 0.25 & 0.55 \\
\hline & Hom. tr. & $2713 \times 764$ (No. 3$)$ & $\left(l e u^{+} i l v^{-}\right)$ & 0.5 & - & - & - \\
\hline & Hom. tr. & $2713 \times 764$ (No. 4$)$ & $\left(l e u^{-} i l v^{+}\right)$ & $\underline{-1}$ & 0.8 & - & - \\
\hline & Het. & 6455 & $\left(l e u^{-} i l v^{\prime}\right)$ & 0.02 & 0.002 & 0.009 & 0.24 \\
\hline & Hyb. & $2713 \times 6455($ No. I $)$ & $\left(l e u^{+} i l v\right)$ & 0.5 & 0.5 & 0.68 & 0.82 \\
\hline & Hyb. & $2713 \times 6455($ No. 3$)$ & $\left(l e u^{+} i l v^{-}\right)$ & 0.9 & & - & - \\
\hline & Hyb. & $2713 \times 6455$ (No. 5$)$ & $\left(l e u^{-} i l v^{+}\right)$ & 8 & 0.03 & 一 & - \\
\hline \multirow[t]{8}{*}{ III } & Hom. & 746 & $\left(l e u^{-} i l v^{+}\right)$ & $4 \cdot 6$ & $4 \cdot 4$ & 0.24 & 0.65 \\
\hline & Hom. tr. & $2713 \times 746($ No. I $)$ & $\left(l e u^{+} i l v^{+}\right)$ & $2 \cdot 9$ & $2 \cdot 6$ & 0.42 & 0.76 \\
\hline & Hom. tr. & $2713 \times 746$ (No. 3$)$ & $\left(l e u^{+} i l v^{-}\right)$ & $6 \cdot 5$ & - & - & - \\
\hline & Hom. tr. & $2713 \times 746($ No. 4$)$ & $(l e u-i l v)$ & $\underline{3}$ & $1 \cdot 9$ & - & - \\
\hline & Het. & 6455 & $\left(l e u^{+} i l v^{\prime}\right)$ & $0 \cdot 1$ & O.OI & $<0.0$ I & 0.42 \\
\hline & Hyb. & $2713 \times 6455$ (No. 2$)$ & $(l e u+i l v)$ & $0 \cdot 2$ & 0.2 & 0.59 & 0.91 \\
\hline & Hyb. & $2713 \times 6455$ (No. 4$)$ & $\left(l e u^{+} i l v\right)$ & 0.9 & - & - & - \\
\hline & Hyb. & $2713 \times 6455$ (No. 6$)$ & $\left(l e u^{-} i l v^{+}\right)$ & - & 0.25 & - & - \\
\hline \multirow[t]{7}{*}{ IV } & Hom. & 746 & (Prep. 8) & $3 \cdot I$ & $3 \cdot 2$ & ND & ND \\
\hline & & $\left(l e u^{+} i v^{+}\right)$ & (Prep. 9) & $2 \cdot 9$ & $3 \cdot 0$ & ND & ND \\
\hline & & & (Prep. 6) & $0 \cdot 8$ & 0.8 & ND & ND \\
\hline & Hyb. & $2713 \times 6455$ (No. 2$)$ & & & & & \\
\hline & & $\left(l e u^{+} i l v^{+}\right)$ & (Prep. 5) & 0.6 & 0.5 & ND & ND \\
\hline & & & (Prep. 6) & $0 \cdot 2$ & 0.3 & ND & ND \\
\hline & & & (Prep. 2) & $0 \cdot 2$ & 0.2 & ND & ND \\
\hline \multirow[t]{7}{*}{ V } & Hom. & $746\left(l e u^{+} i l v^{+}\right)$ & (Prep. 6) & $3 \cdot 2$ & $3 \cdot 2$ & 0.40 & 0.40 \\
\hline & Hyb. & $2713 \times 6455$ (No. 2$)$ & & & & & \\
\hline & & $\left(l e u^{+} i l v^{+}\right)$ & (Prep. 2) & 0.4 & 0.4 & 0.67 & 0.59 \\
\hline & & & (Prep. 3) & 0.08 & 0.06 & 0.50 & 0.67 \\
\hline & Het. & $6455\left(l e u^{+} i l v^{+}\right)$ & (Prep. 1) & $0 \cdot 01$ & 0.004 & - & - \\
\hline & & & (Prep. 2) & 0.03 & 0.002 & 0.027 & 0.32 \\
\hline & & & (Prep. 3) & 0.02 & 0.001 & 0.009 & 0.12 \\
\hline
\end{tabular}

* Different batches of competent recipient were used in different experiments.

$\dagger$ Hom., homologous donor; Hom. tr., homologous transformant obtained by transforming $B$. subtilis strain $2713\left(l e u^{-} i l v^{-}\right)$with DNA from strain $746\left(l e u^{+} i l v^{+}\right)$; Het., heterologous donor; Hyb., hybrid, or heterologous transformant, obtained by transforming strain 2713 with DNA from B. subtilis var. niger strain $6455\left(l e u^{+} i l v^{+}\right)$.

¥ The number of the hybrid is given in parentheses. Prep., preparation.

$\S \mathrm{ND}$, Not done; - not determinable.

disappearance of differential activity in the leu-ilv region is clearly seen in the final columns of Table 2, which contain the measurements of cotransfer or linkage of the leu and ilv markers. With homologous DNA, the probability of a le $u^{+}$transformant also receiving the ilv marker is similar to the probability of an $i l v^{+}$transformant receiving the leu marker. This probability was not affected by the concentration of transforming DNA used (not 
shown) and was fairly reproducible. With heterologous DNA from B. subtilis var. niger, the probability of an $i l v^{+}$transformant acquiring the leu marker is about the same as in an homologous cross. On the other hand, the probability of a $l e u^{+}$transformant acquiring the $i l v$ marker is reduced by about the same extent as $i l v^{+}$relative to $l e u^{+}$transformations. In other words, an asymmetry of integration is observed in an heterologous cross, similar to the polarity previously reported by Chilton \& McCarthy (1969): while the over-all efficiency of heterologous integration is reduced, more integrations of $i l v^{+}$are accompanied by integrations of leu than the converse. With hybrid DNA of either type, however, the asymmetry disappears, indicating that a reduction in transformation efficiency brought on by heterology is not necessarily accompanied by asymmetry. There is also some indication that linkage may be slightly tighter between leu and ilv in hybrid DNA than in homologous DNA.

\section{DISCUSSION}

Some of the inefficiency of heterospecific transformation of the leu-ilv locus of B. subtilis must be due to heterologous sites in the donor DNA, sites that may be integrated without modification into the recipient genome. This is shown by the fact that B. subtilis DNA that has acquired a marker from a heterologous source (var. niger) can retain some of the original inefficiency of transferring that marker into the $B$. subtilis genome. The site(s) responsible for this portion of the inefficiency causes an equal reduction in transformation at the linked leu and $i l v$ loci, and is separable but closely linked to these loci since it accompanied the heterologous donor marker in three out of the six niger $\times$ subtilis hybrids examined. There is presumably at least one other site that distinguishes the DNA of these two strains: a site that causes a further reduction in the efficiency of the heterologous cross. This site may be the same as or separate from the one that is responsible for the asymmetry in integration of the leu and ilv loci.

In the light of the explanation given above for the inefficiency of heterologous transformation, a greater number of sites would be supposed to distinguish the trp-his-tyr regions than the leu-ilv regions of the niger and 68 strains of $B$. subtilis; that is to say, the leu-ilv region has been more conservative in its evolution than the trp-his-tyr region. The leu-ilv region shares this conservatism with the unlinked str locus (Chilton \& McCarthy, 1969).

It might be argued that sequence heterology is the cause of the inefficiency of heterospecific transformation at 'conservative' loci but that other factors are the causes of this inefficiency at other loci. The argument is vitiated, however, by the recent findings of genetically hybrid DNA for the thy locus determining thymidylate synthetase, which has undergone considerable differentiation between the sanguis and pneumoniae species of Streptococcus (Ravin \& Chakrabarti, 1975).

The authors gratefully acknowledge a grant (AI-09I17) awarded by the National Institute of Allergy and Infectious Diseases.

\section{REFERENCES}

Biswas, G. D. \& Ravin, A. W. (1971). Heterospecific transformation of Pneumococcus and Streptococcus. IV. Variation in hybrid DNA produced by recombination. Molecular and General Genetics IIo, I-22.

Bott, K. F. \& Wilson, G. A. (1967). Development of competence in the Bacillus subtilis transformation system. Journal of Bacteriology 94, 562-570.

BotT, K. F. \& Wilson, G. A. (1968). Metabolic and nutritional factors influencing the development of competence for transfection of Bacillus subtilis. Bacteriological Reviens 32, 370-378.

Chilton, M.-D. \& MCCarthy, B. J. (1969). Genetic and base sequence homologies in Bacilli. Genetics 62, 697-710. 
HoтchкISs, R. D. (1957). Isolation of sodium deoxyribonucleate in biologically active form from bacteria. In Methods in Enzymology, vol. 3, pp. 692-696. Edited by S. P. Colowick and N. O. Kaplan. New York: Academic Press.

Nester, E. W., Schafer, M. \& Lederberg, J. (1963). Gene linkage in DNA transfer: a cluster of genes concerned with aromatic biosynthesis in Bacillus subtilis. Genetics 48, 528-55 I.

Ravin, A. W. \& Chakrabarti, T. (I975). Genetic hybridization at the unlinked thy and str loci of Streptococcus. Genetics 8I, 223-24I.

Saito, H. \& MiURA, K. (I963). Preparation of transforming deoxyribonucleate by phenol treatment. Biochimica et biophysica acta 72, 6I9-629.

Smith, N. R., Gordon, R. E. \& Clark, F. E. (1946). Aerobic Mesophilic Sporeforming Bacteria, pp. I-II 2. U.S. Department of Agriculture Miscellaneous Publication No. 559.

SPIZIZEN, J. (1958). Transformation of biochemically deficient strains of Bacillus subtilis by deoxyribonucleate. Proceedings of the National Academy of Sciences of the United States of America 44, 1072-1078.

WiLson, G. A. \& Young, F. E. (1972). Intergenotic transformation of the Bacillus subtilis genospecies. Journal of Bacteriology III, 705-716. 